\title{
Accounting Practices of Small and Micro Enterprises in North Shewa Zone Amhara Regional State of Ethiopia
}

\author{
Gashaw Belete Mekonnen \\ Department of Accounting and Finance, College of Business and Economics, Debre Berhan University, Debre Berhan, Ethiopia \\ Email Address: \\ gashelove05@gmail.com

\section{To cite this article:} \\ Gashaw Belete Mekonnen. Accounting Practices of Small and Micro Enterprises in North Shewa Zone Amhara Regional State of Ethiopia. \\ Journal of Investment and Management. Vol. 8, No. 2, 2019, pp. 40-47. doi: 10.11648/j.jim.20190802.12
}

Received: December 21, 2019; Accepted: April 4, 2019; Published: April 29, 2019

\begin{abstract}
The government of Ethiopia gives special emphasis for small and micro enterprises in recent periods for the development of the country and faces various challenges. One of the most critical problems is related to proper recording of accounts and preparation of financial reports. The main objective of this study therefore to examine the accounting practices of Small and Micro enterprises in north shewa zone of Amhara regional state of Ethiopia. 305 Small and micro enterprises were selected as samples from five town administrations of north shewa zone. The researcher used purposive non probability sampling techniques to select towns and disproportionate stratified random sampling techniques which involve dividing the population into homogeneous subgroups in to sector wise (construction, urban agriculture, manufacturing and trade). The study was revealed that more than $50 \%$ of the respondents do not keep the accounting records totally due to the reason that lack of accounting knowledge, required more cost, waste of time, more labor intensive. Even for those respondents who prepare accounting records the main constraint faced with them for proper accounting record is lack of accounting knowledge. Therefore, the researcher recommended that the concerned governmental institutions Debre Berhan University, North Shewa zone small and micro enterprises office and north shewa zone TVET colleges arrange training `sessions for those enterprises.
\end{abstract}

Keywords: Accounting Practices, Small and Micro Enterprises, North Shewa Zone, Ethiopia

\section{Introduction}

\subsection{Back Ground of the Study}

It is often said that the world has now become a global village. Currently, the way and manner individuals, enterprises and nations react to this assertion of globalization tells it all. Specifically with business enterprises, this era requires much more inputs of some sort to be able to establish, survive and grow in order to properly assess the concept of globalization. However, to merely survive as a business enterprise requires a rigorous application of accounting to every incident in a proper manner. This is due to the fact that, resources of business enterprises are often limited and their proper control in terms of allocation and performance measurement has become the order of the day.

Accounting plays a critical role in the success or failure of contemporary business institutions. Accounting systems are responsible for recording, analyzing, monitoring and evaluating the financial condition of companies, preparation of documents necessary for tax purposes, providing information support to many other organizational functions [1]. In the context of SMEs, accounting information is important as it can help the firms manage their short-term problems in critical areas like costing, expenditure and cash flow, by providing information to support monitoring and control [17].

The contribution of Small and Micro Enterprises (SMEs) to the economic development of most developing countries is huge. Providing employment for almost two-thirds of the countries working population, contributing to the government revenue generation through the payment of income tax, as well as providing income in terms of profits, dividends and wages to households just to mention a few, has been the ultimate trademark of SMEs to a developing country of which Ethiopia is no exception. [18] contended that, growing SMEs will also contribute to expanding the size of the directly productive sector in the economy; generating tax revenue for the government; and, all in all, facilitating poverty reduction through fiscal transfers and income from 
employment and firm ownership.

For most developing countries including Ethiopia, achieving low unemployment, improving income levels and reducing poverty which eventually lead to economic success largely depends on whether our SMEs are doing well or not.

For the SMEs also to do well there is the need for them to attract and secure finance. Providers of finance will not invest or provide funds unless they are assured that they will not lose their investment. Most providers of finance assure themselves with financial accounting information generated from an adequate accounting system in order to reduce risk.

The question now is that, do the SMEs have in place proper books of accounts to generate the much needed accounting information that providers of finance and other business partners require? The answer to the above question makes it imperative for the researcher to look at financial accounting practices of SMEs in Amhara region, north shewa zone.

The study is relevant in the Ethiopian context given the important role SMEs play in the economic development. There is a need to explore the accounting practices of SMEs in north shewa zone and to ascertain whether they are able to meet the expectations of finance providers. This will improve SMEs access to funds and improve the performance of the general level of economic activity. The study adds to the literature on accounting practices of SMEs and therefore adds to a body of knowledge.

\subsection{Statement of the Problem}

The main objective of accounting systems is to provide accurate information to owners and managers of SMEs operating in any business for use in the measurement of financial performance. Finally, the importance of financial performance measurement to any enterprise, big or small, cannot be over-emphasized [11]. In other words, since profit maximization is most often given priority for business entities, the accounting bases, concepts and principles adopted to capture and report all the relevant accounting information to ensure reliability in its measurement. Profits reflect changes in wealth of owners and this can explain why major economic decisions in business are centered on financial performance as measured by profitability [5].

Based on the intolerable outcome that improper accounting practices can have on SMEs, it is essential that the accounting practices of SMEs supply complete and relevant financial information needed to improve economic decisions made by entrepreneurs. Based on the researcher knowledge the issues related to accounting practices of SMEs in north shewa zone is not scientifically investigated. Finally, this research looks for to emphasis the need for it. The study also has important policy implications for the government of Ethiopia and SMEs in particular.

\subsection{Objectives of the Research}

\subsubsection{General Objective}

The general objective of this study is to investigate
Accounting Practices of small and micro enterprises in north shewa zone of Amhara Regional state of Ethiopia.

\subsubsection{Specific Objectives}

1. To find out the types of accounting records being kept and maintained by SMEs.

2. To examine the extent to which accounting information is being used in measuring financial performance by SMEs.

3. To analyze the completeness of accounting controls by SMEs as a source of information for economic decision making.

4. To identify challenges associated with accounting records keeping of SMEs.

\subsection{Significance of the Study}

The SMEs play a great role in Ethiopian economy. "Very few researches have been conducted in this area such as [8]". This study was conducted to investigate the extent to which the SMEs owners or managers keep records of their business operations were justified. It is envisaged that the findings of this study was likely to provide a more comprehensive picture of the current status of SMEs in terms of purpose of recordkeeping and control. A more comprehensive picture would, in turn, lead to a better understanding of this phenomenon and thereby the development of more effective strategies to aid effective operation of the SMEs.

This study was serve to preserve many of SMEs from failure in the sense that it could raise awareness for the need for training and the use of the available tools described in the study to measure financial performance. SMEs might then be able to foresee failure and change of their actions and attitude in time to prevent it. Therefore, the result focused to create the awareness of entrepreneurs to organize the accounting records properly, in order to encourage the success of their business and they can meet the obligation of providing information for the government, lenders of finance and creditors.

\subsection{Delimitation of the Study}

This research was carried out in Amhara region, North Shewa Zone of Ethiopia and in particular, the focus is on SMEs operating at five towns in North Shewa namely Debre Berhan, Alem Ketema, Mehal meda, Shewarobit and Ataye. The study focused on accounting practices in SMEs, since it is a major challenge in generating adequate accounting information for use in decision making.

In considering significant aspects of the accounting practices, this study concentrated on internal factors of SMEs but not captured much external environment factors such as the accounting practices related to conducive environment, politics, and different beaurocratic related factors. The internal business function of the greatest concern in this study is accounting practices because it is relevant to the problems pertaining to small and micro enterprises at the moment. 


\section{Related Literature Review}

\subsection{Small and Micro Enterprise Defined}

There are several ways of defining a small or micro business. Regardless of their differences, all the definitions agree on the common views that small or micro businesses employ few persons and are characterized by a relatively small amount of capital and turnover. There is no single definition that can capture all the dimensions of "micro", "small", "medium" or "large" nor can it expect to reflect the differences between firms, sectors or countries at different levels of development [13]. For instance, that, an annual turnover of less than UDS100, 000 would probably define a micro business in the United States of America but could well include a medium-sized firm in other economies. The United States Committee for Economic Development for Small Businesses indicates that, "a small business will have at least two of the following characteristics: Managers are also owners; Owners supplied capital; Area of operation mainly local; and Small in size within the industry". The main criteria used throughout the world to describe small businesses as including: Sales value; Number of employees; Financial strength; Relative size; Initial capital outlay; Comparison with its past standards; Independent ownership; and Type of industry.
Micro enterprise as "a business involving one to five persons (typical a sole trader). Its character would be such that its activities are simple enough to be managed directly on a person-to-person basis and the scale of the operations means it is unlikely to need or be able to afford to devote significant staff time to accounting. Its operations are likely to concern a single product, service or type of operations. Only basic accounting is needed to record turnover, control expenses and profitability, and if necessary, compute profits for tax purposes. It is unlikely to have extensive credit transactions".

It also defines a small enterprise as "a business employing 6 to 50 persons. Such a business would probably have several lines of activity and conceivably more than one physical location. It would probably need loan finance and have to report to lenders. Its payroll would potentially be quite large and relatively complex and it would need management information on turnover and costs analyzed by product line.

\subsection{Small and Micro Enterprise in Ethiopia}

According to the Small and Micro Enterprises Development Strategy of Ethiopia (published 2011) the working definition of SMEs based on capital and Labor is illustrated as.

Table 1. The working definition of SMEs in Ethiopia based on capital and Labor employed.

\begin{tabular}{|c|c|c|c|c|}
\hline S no & Enterprise level & Sector & Hired labor & Capital \\
\hline \multirow[t]{2}{*}{1.} & Micro & Industry & $\leq 5$ & $\$ 6000$ or $£ 4500$ or $\leq$ birr 100,000 \\
\hline & & Service & $\leq 5$ & $\$ 3000$ or $£ 2200$ or $\leq$ Birr 50,000 \\
\hline \multirow[t]{2}{*}{2.} & Small & Industry & $6-30$ & $\$ 90,000$ or $£ 70,000 \leq$ Birr $1,500,000$ \\
\hline & & Service & $6-30$ & $\leq$ Birr 500,000 \\
\hline
\end{tabular}

Industry sector includes: Manufacturing, Construction and Mining etc; Service sector includes: Trade, Transport, Hotel and tourism, Information Technology, and Repair services etc.

\subsection{Accounting System and Controls for the Small and Micro Enterprises}

A good accounting system is not only judged by how well records are kept but by how well it is able to meet the information needs of both internal and external decisionmakers [12]. It is common for qualified accountants to do a good job of keeping records up to date but they fail to provide information needed by decision-makers [4]. For a businessperson, an accounting system should be capable of providing the following information:

a) Interim statements, quarterly or six-monthly that can provide information about the progress of the business. Such statements need not be detailed, but capable of addressing the special needs of the business. Such documents can also be circulated, if necessary, among external users such as lenders.

b) Efficiency cash flow planning is very important for the small business. An annual cash flow forecast, reviewed periodically, could indicate overall financial requirements. Such a statement can be prepared only with the help of a well-designated accounting system [10].

c) An accounting system, in addition to providing financial statements, must be capable of generating other useful information in the form of reports. These include aged accounts receivable, aged accounts payable, stock and bank balances, etc.

d) In the case of manufacturing enterprises, cost records are very useful in estimating costs and determining prices. The accounting system for such enterprises must provide reliable data for cost estimation.

Regarding accounting control procedures for small and micro business enterprises, it is important to have a system of control over all business activities, as a well-designed and properly implemented control system can ensure: Protection of resources against waste and fraud; Accuracy and reliability in accounting data; and Success in the evaluation of the performance of the business.

\subsection{Accounting Practices of SMEs}

A thread of the literature looks at the importance of accounting systems on the basis of its application in assessing the performance of businesses by all stakeholders. 
In the process of planning for profit, financial information is assembled in a way that can help make informed judgment and take decisions concerning the organization. An emphasis is laid on the significance of keeping proper books of accounts since it enables small businesses to have accurate information on which to base decisions [3, 7]. SMEs project purchase and sales, determine break-even point, and make a wide range of other financial analyses based on accounting information. The study contends that, lack of proper accounting records has seen the closure of some businesses, and thus makes it a significant issue for business success. The quality of accounting information utilized within the SME has a positive relationship with an entity's performance and survival. Similarly, it has been emphasized that there is the need for financial information for small and micro business units due to the volatility normally associated with their situation such as unstable cash and profit positions, and reliance on short-term borrowing $[9,16]$. Accurate recordkeeping of SMEs transactions is essential to the growth of the enterprises [2]. The findings of this study showed that the owners/managers of the SMEs had positive attitude towards the recordkeeping but lacked knowledge of the recording.

Accounting is one of the important types of information for decision making both within and outside the organization, and the quality of this information gauged by its relevance and its reliability for a particular decision is equally important [15]. Many enterprises record their transactions randomly without adherence to any established structures of accounting; hence making it difficult in keeping track of the cash flows in the enterprises. On the other hand accounting information could help SMEs manage short-term problems in such areas as costing, expenditure and cash flow by providing information to support monitoring and control [17].

\subsection{Prior Studies on Small and Micro Businesses}

A bleak state of affairs regarding how accounting and control systems are kept and exercised respectively by most SMEs. It appears that these crucial ingredients of business management have been relegated to the very background [14]. The results are somehow a reflection of the assertion by most SMEs that they were making losses. This is perhaps as a direct result of the absence of important accounting controls in their businesses which consequently exposed their operations to lapses, misappropriations and general inefficiencies. The majority of SMEs (especially those in the micro business sector) accounts preparation and perhaps book-keeping to a greater extent has to do with satisfying external partners banks, taxation and so on.

SMEs do not maintain proper books of accounts because owners do not appreciate the need to keep accounting records, lack the necessary accounting knowledge and blame the cost of hiring accounting professional. Consequently, the application of accounting information to support assessment of financial performance by SMEs in Ghana is inefficient [11].
A study revealed that SMEs do not keep complete accounting records because of lack of accounting knowledge and the cost of hiring professional accountants. As a result, there is inefficient use of accounting information to support financial performance measurement by SMEs [2]. This made it difficult for the entrepreneurs to calculate their business profit efficiently. Failure of keeping of accurate records was highly blamed on the lack of skills in this field. The study further discovered that the owners and managers of SMEs were highly willing to learn more about how to keep accurate records of their business transactions.

\section{Research Design and Methodology}

\subsection{Research Design}

The target of this investigation is to describe a set of phenomenon or situation in relation to accounting practices of small and micro enterprises (SMEs). Therefore, descriptive research design is appropriate for this study.

\subsection{Sources and Method of Data Collections}

The researcher mainly used Primary data sources; Primary data sources are original or un-interpreted accounts pertaining to people, objects, or events that are collected for the task at hand. As widely accepted, the survey method is a fact-finding study that involves adequate and accurate interpretation of findings [6]. Therefore, primary data were collected using questionnaires (a research instrument consisting of a set of questions (items) intended to capture responses from respondents in a standardized manner); in the selected towns of North Shewa Zone) from owners/ managers of the enterprise.

\subsection{Population}

The target population of the study was comprised of 1287 registered SMEs in North Shewa Zone towns' administration of Amhara Regional state of Ethiopia which were found in the growth and maturity stage. The questionnaires were divided into three sections: Demographic Characteristics of Respondents, Profile of the entity and Accounting practices which encompasses recording, control, preparation of financial reports and its challenge.

\subsection{Sample and Sampling Techniques}

The sample has been taken from selected towns of north shewa zone of Amhara regional state of Ethiopia mainly from (Debre Berhan, Alem Ketema, Mehal meda, Shewarobit and Ataye). The researcher used purposive non probability sampling techniques to select towns and Disproportionate stratified random sampling techniques which involve dividing the population into homogeneous subgroups in to sector wise (construction, urban agriculture, manufacturing and trade).

\subsection{Sample Size}

The basis for calculating the size of samples is that there is a minimum sample size required for a given population to 
provide estimates with an acceptable level of precision. Any sample larger than this minimum size (if chosen properly) should yield results no less precise, but not necessarily more precise, than the minimum sample. Therefore, in this study the researcher determined the sample size using Yamane simplified formula of 1967, as follows:

$$
\mathrm{n}=\mathrm{N} / 1+\mathrm{N}(\mathrm{e})^{2}
$$

Where:

$\mathrm{n}$ is the sample size,

$\mathrm{N}$ is the population size, and

$\mathrm{e}$ is the level of precision.

Therefore, $\mathrm{n}=1287 / 1+1287(.05)^{2}=305$

Based on this formula the researcher selected 305 SMEs operating in 5 town administrations of north shewa zone. For easily managing of data and accurate information researcher excluded those enterprises at start up stages not yet operating.

\subsection{Data Analysis Procedure}

Data analysis is a body of methods that help to describe facts, detect patterns, develop explanations, and test hypotheses. So, the data in this research were collected by using questionnaire and analyzed using tabulation.

\section{Result and Discussion}

It deals with the analysis and discussion of the descriptive results. From the total 305 questionnaires distributed to respondents 295 completed well and the remaining 10 were not returned. Therefore, the analysis of data was based on 295 returned responses.

Table 2. Sex, Age and Educational Background of respondents.

\begin{tabular}{lll}
\hline & Frequency & percentage \\
\hline Sex & & \\
Male & 190 & 64.4 \\
Female & 105 & 35.6 \\
Total & 295 & 100 \\
Age & & \\
20-25 years & 56 & 19 \\
26-30 years & 95 & 32.2 \\
31-35 years & 73 & 24.7 \\
36-40 years & 41 & 13.9 \\
Above 40 year & 30 & 10.2 \\
Total & 295 & 100 \\
Educational Background & & \\
Illiterate & - & - \\
Elementary Completed & - & - \\
Grade 10 completed & 58 & 19.7 \\
Grade 12 completed & 47 & 15.9 \\
TVET completed & 105 & 35.6 \\
Degree holder & 85 & 28.8 \\
Total & 295 & 100 \\
\hline
\end{tabular}

Source: Survey Data, 2018.

From the above table 2 out of the total 295 complete responses 190(64.4\%) comprises males while the remaining $105(35.6 \%)$ were females, which indicates the government of Ethiopia should strive to bring females to the business stream of MSEs. One can also see that $224(75.9 \%)$ of the respondents found at the age of less than 35 years. Under these productive age category people can contribute a lot for the development of the country. Therefore, the concerned body should assist them to encourage more. From table 2 again the education status of respondents indicated that $58(19.7 \%)$ were grade ten completed, $47(15.9 \%)$ were grade twelve completed, 105 (35.6\%) were TVET completed and the remaining 85 (28.8\%) were degree holders. This result indicated that majority of the respondents were TVET completed, this happened due to the government gave emphasis to job creation instead of searching for employment. So, TVET graduates were more eager than others up to the nearby years since they trained more practically than others.

Table 3. Investment sector, Age of investment and number of Labor employed in the enterprise.

\begin{tabular}{lll}
\hline & Frequency & Percentage \\
\hline Investment sector & & \\
Construction & 73 & 24.8 \\
Manufacturing & 85 & 28.8 \\
Trade & 90 & 30.5 \\
Urban Agriculture & 47 & 15.9 \\
Total & 295 & 100 \\
Age of investment & & \\
1-5 years & 140 & 47.5 \\
6-10 years & 113 & 38.3 \\
11-15 years & 42 & 14.2 \\
Above 15 years & - & - \\
Total & 295 & 100 \\
Labor employed & & \\
Permanently employed & 165 & 25.5 \\
Temporarily employed & 76 & 11.7 \\
Contract & 210 & 32.5 \\
Others & 196 & 30.3 \\
Total & 647 & 100 \\
\hline
\end{tabular}

Source: Survey Data, 2018.

Table 4. Keeping Accounting Records.

\begin{tabular}{lll}
\hline & Frequency & percentage \\
\hline $\begin{array}{l}\text { Do you keep accounting records in your } \\
\text { enterprise? }\end{array}$ & \\
Yes, in a proper manner & 40 & 13.6 \\
Yes, but rarely & 98 & 33.2 \\
Not at all keep the records & 157 & 53.2 \\
Total & 295 & 100 \\
Reason for keeping accounting records & & \\
For Tax purpose & - & - \\
For Loss and profit sharing & 28 & 20.3 \\
To know revenue and expenses & 30 & 21.7 \\
Getting loan & 26 & 18.8 \\
To identify payable/receivable accounts & 7 & 5.1 \\
To determine progress of business & 47 & 34.1 \\
Total & 138 & 100 \\
Reason for not keeping accounting & & \\
records & & \\
Time consuming & 10 & 6.4 \\
Required more cost & 31 & 19.7 \\
Lack of accounting knowledge & 98 & 62.4 \\
Levying of more taxes & - & - \\
More labor intensive & 18 & 11.5 \\
Total & 157 & 100 \\
The responsible body handling & & \\
accounting records & 84 & 60.9 \\
Owner/manager & & \\
\hline
\end{tabular}




\begin{tabular}{lll}
\hline & Frequency & percentage \\
\hline Internal accountant & 34 & 24.6 \\
External accountant & 20 & 14.5 \\
Total & 138 & 100 \\
\hline
\end{tabular}

Source: Survey Data, 2018.

Table 3 above shows that from the total 295 projects trade, manufacturing, construction and urban Agriculture accounted 90(30.5\%), 85 (28.8\%), 73 (24.8) and 47 (15.9\%) respectively. When come to age of investment $253(85.76 \%)$ were less than age of 10 years. None of these enterprises exist before 15 years since it is a recent trend the government of Ethiopia give emphasis for small and micro enterprises. Table 3 above also depicted that from the total 647 labors employed in 295 enterprises 210 (32.5\%) were contract workers, while 196 (30.3) were others which includes the owners, Family members and causal employees. Only 165 $(25.5 \%)$ of employees were permanently employed.

Regarding keeping accounting records table 4 above demonstrated that $157(53.2 \%)$ do not keep records totally, $98(33.6 \%)$ were keep the records in rare cases and 40 $(13.6 \%)$ keep the accounting records in a proper manner. 47 $(34.1 \%)$ of the enterprises keep the records for determining of progress of the business, while $7(5.1 \%)$ were used the accounting records to identify payable/receivable accounts. From the total 157 SMEs not keeping accounting records 98 $(62.4 \%)$ replied that they lack accounting knowledge how to prepare the records which is similar to [11] found that SMEs do not maintain proper books of accounts because owners do not appreciate the need to keep accounting records, lack the necessary accounting knowledge and blame the cost of hiring accounting professional in Ghana SMEs. 10 (6.4\%) responses that they do not keep the accounting records since it take time. None of the respondents replied that the reason for not keeping accounting recording for panic of more taxes since in MSEs in Ethiopia taxed based on assessment i.e assessments are prepared as of a specific date each year and often based on recent sales of comparable properties in the vicinity and local governments used these tax assessment as the basis of property tax bill. Table 4 above also indicated that in $84(60.9 \%)$ of enterprises owners/ managers were responsible for handling of the accounting records. This indicates that most of micro and small enterprises run by family members and they do not worry about whether the record is kept in a proper manner since they mainly lack accounting knowledge and its significance in economic decision making.

Table 5. Control mechanism of cash receipts.

\begin{tabular}{lll}
\hline How can you control cash receipt in your organization & Frequency & Percentage \\
\hline Deposited in to bank instantaneously & 90 & 30.5 \\
Keep in cash on hand & 35 & 11.9 \\
Owner personal safe keeping & 98 & 33.2 \\
By purchasing productive assets & 72 & 24.4 \\
Total & 295 & 100 \\
\hline
\end{tabular}

Source: Survey Data, 2018.

From table 5 above $98(33.2 \%)$ and $90(30.5 \%)$ of respondents replied that the amount of cash was controlled under the owners personal safe keeping and immediately deposited in to bank respectively. The result also indicates that most of the enterprises do not keep the amount of cash receipts on hand, it may somewhat reduces the stealing of cash.

Table 6. Challenges for preparing of financial statements/reports for those keeping records.

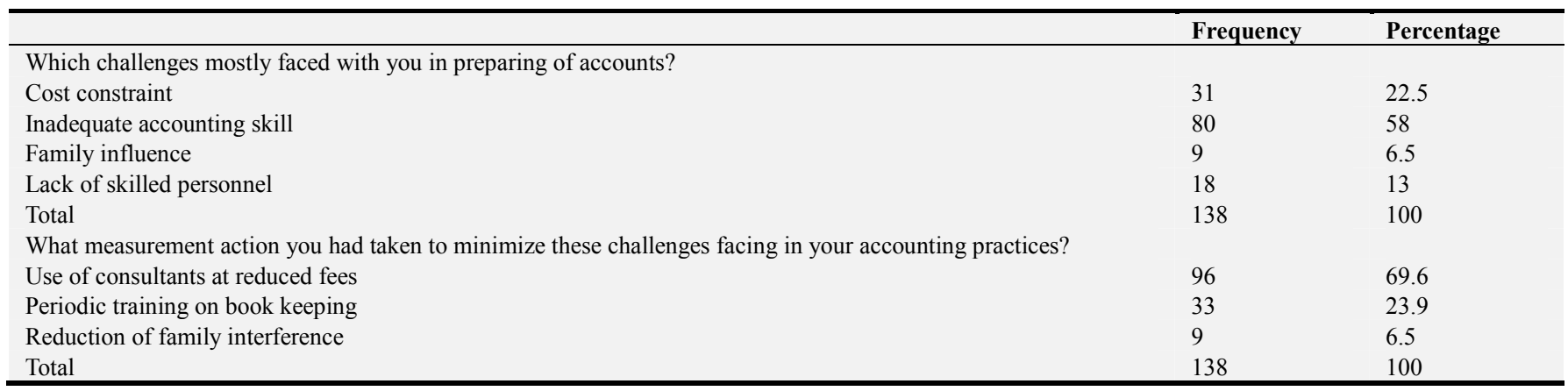

Source: Survey Data, 2018.

From the total 138 respondents who keeps accounting records shown in table 6 above 80 (58\%) replied that inadequate accounting skill was the major challenge for keeping accounting records and preparation of financial reports, while $31(22.5 \%)$ faced cost constraints to prepare their financial reports in a proper manner. Table 6 also shows that $96(69.6 \%)$ of respondents tried to use consultants and $33(23.9 \%)$ had taken periodic training on book keeping as a remedial action to minimize the challenges faced in accounting records and reports. 
Table 7. Support from the concerned body.

\begin{tabular}{lcc}
\hline Is there any support from the concerned government for the proper recording of accounts and preparation of reports & Frequency & Percentage \\
\hline Yes & 98 & 33.2 \\
No & 40 & 13.6 \\
Missing & 157 & 53.2 \\
Total & 295 & 100 \\
\hline
\end{tabular}

Source: Survey Data, 2018.

Table 7 above describes from the government side for the proper recording of accounts and preparation of financial reports. From this one can understand that more than $50 \%$ of respondents omitted since totally they do not keep the records and prepare financial reports, and nobody gave support regarding record keeping and preparation of financial reports due to size of their businesses they do not bother about records these were mainly the micro enterprises. 98 (33.2\%) were taken trainings to keep their accounting records properly for proper recognition of revenues and expenses, and in rare cases for access to loan. 40(13.6\%) did not get any support from the concerned body even if they prepared records by the consent of the owners.

\section{Conclusion}

Based on the finding of the study the researcher found that from the total respondent's females accounted 35.6\%. Even if the government of Ethiopia recently gives emphasis to small and micro enterprises for the development of the country the participation of females still needs improvement especially in construction and manufacturing sectors.

As accounting is the language of business which is used to communicate business information to make the informed judgment and decision. Some study argued that accounting information could help SMEs manage short-term problems in such areas as costing, expenditure and cash flow by providing information to support monitoring and control such as [17].

Even though the most important part of accounting is recording the accounts the study found that more than $50 \%$ of enterprises do not keep records only $13.6 \%$ keep the records properly. The major reason behind not keeping the records includes lack of accounting knowledge, required more labor, required more cost to hire professionals and wastage of time. The result indicates that the awareness and knowledge of accounting practices in small and micro enterprises is low.

\section{Recommendations}

From the conclusion driven above participation of females in Small and Micro Enterprises still needs improvement especially in construction and manufacturing sectors Therefore, the concerned government should strive to accommodate the difference and bring women in the main stream of development. The result also indicates that the awareness and knowledge of accounting practices in small and micro enterprises is low. So, the concerned body should create awareness and provide training in book keeping and accounting, the main burden may levied to Debre Berhan
University, North Shewa Zone poly technic colleges and north shewa zone small and micro enterprise office.

\section{References}

[1] Amidu M., John E. \& Joshua A. (2011). E-Accounting Practices among Small and Medium Enterprises in Ghana. Journal of Management Policy and Practice vol. 12 (4) 2011.

[2] Bancy, W., Muchira. (2012). Record Keeping and Growth of Micro and Small Enterprises, A Case Study of Thika Municipality in Kenya. The School of Business, Kenyatta University.

[3] Biryabarema, E. (1998). Small Scale Business and Commercial Banks in Uganda. Kampala: Makerere University Press.

[4] Clute, R. C. and Gitman, G. B. (1980). A Factor Analytic Study of the Causes of Small Business Failure, Journal of Small Business Management, USA.

[5] Cooley, P. L., \& Edwards, C. E. (1983). Financial objectives of small firms. American Journal of Small Business, 8 (1), 27 31 .

[6] Cooper DR, \& Schindler PS (2003). Business research methods. Irwin: McGraw-Hill. NY.

[7] Copeland, R. M., \& Dascher, P. E. (1978). Managerial Accounting. New York, NY: John Wiley.

[8] Deresse,M, Lakew and Zerihun, A, Birbirsa. (2017). Accounting and Reporting Practices of Micro and Small Enterprises in west oromia region, Ethiopia. Research Journal of Finance and Accounting.ISNN 2222-1697(Paper) V8, No 9, 2017.

[9] Dodge, H., Fullerton, S., \& Robbins, J. (1994). Stage of the organizational life cycle and competition as mediators of problem perception for small businesses. Strategic Management Journal, 15, 121-134. http: //dx.doi.org/10.1002/smj.4250150204.

[10] Fuller, S. (1978). Just Say No to Wall Street, Harvard business Review

[11] Gilbert, K., Amoako. (2013). Accounting Practices of SMEs: A Case Study of Kumasi Metropolis in Ghana. Canadian Center of Science and Education. International Journal of Business and Management; Vol. 8, No. 24; 2013, ISSN 18333850 E-ISSN 1833-8119.

[12] Hussein, M. E. I. M. (1983). Accounting and Control Systems for Small Business. Touché Ross Foundation.

[13] International Labour Organisation (ILO, 1997), General Conditions to Stimulate Job Creation in Small and MediumSize Enterprises, Report of an International Labour Organisation conference, $85^{\text {th }}$ session, Geneva. 
[14] John, K. Mbroh, \& Ben, E. Attom. (2011 ). Accounting and Control Systems Practiced By Small and Micro Enterprise Owners within the Cape Coast Metropolitan Area of Ghana. Asian Journal of Business and Management Sciences ISSN: 2047-2528 Vol. 1 No. 9 [28-47].

[15] Kinney, W. R. (2001). Accounting scholarship: What is uniquely ours? The Accounting Review, 76(2), 275-284. http: //dx.doi.org/10.2308/accr.2001.76.2.275.

[16] McMahon, R. G. P. (1999). Putting SME Financial Reporting into Theoretical and Practical Perspective. Research Paper Series 98-10. The Flinder University of South Australia, Adelaide.
[17] Mitchell, F., Reid, G., \& Smith, J. (2000). Information system development in the small firm: The use of management accounting. London: CIMA Publishing.

[18] Prasad, S., Green, C., \& Murinde, V. (2001). Corporate financial structures in developing economies: Evidence from a comparative analysis of Thai and Malay corporations. Working Paper Series, Paper No 35. Finance and Development Research Programme, University of Manchester, Manchester. 